\author{
Enny Susila Halawa ${ }^{1}$
}

\section{PENERAPAN MODEL PROJECT-BASED LEARNING DALAM MENINGKATKAN MOTIVASI ANAK USIA DINI MELALUI MEDIA KOMIK DI II SD NEGERI 071057 HILIWETO GIDO}

\begin{abstract}
Abstrak
Tujuan penelitian ini adalah untuk meningkatkan kemampuan siswa menulis anak usia dini melalui media komik dengan menerapkan model project-based learning dalam meningkatkan kemampuan menulis anak usia dini melalui media komik siswa kelas II SD Negeri 071057 Hiliweto Gido tahun pembelajaran 2020/2021. Untuk mencapai tujuan ini, peneliti menggunakan metode penelitian tindakan kelas dengan prosedur pelaksanaannya yaitu: 1) perencanaan, 2) tindakan, 3) observasi, dan 4) refleksi. Subjek penelitian ini adalah siswa kelas II SD Negeri 071057 Hiliweto Gido yang berjumlah 30 orang dengan jumlah laki-laki 16 dan perempuan 14 orang. Hasil penelitian ini, ternyata ada peningkatan kemampuan siswa menulis anak usia dini melalui media komik dengan model project-based learning. Hal ini terlihat dari siklus I, dengan nilai rata-rata 64,5, nilai terendah 45 dan nilai tertinggi 80 . Selanjutnya, hasil pada siklus II, dengan nilai rata-rata nilai 77,66, nilai terendah 70 dan nilai tertinggi adalah 95 . Hasil observasi siswa pada siklus I sebesar 78,33\% dan pada siklus II sebesar 93,33\%. Hasil observasi peneliti pada siklus I pertemuan kedua sebesar $72,22 \%$. Sedangkan hasil pengamatan siklus II yaitu pertemuan kedua sebesar $95,83 \%$. Berdasarkan penjelasan di atas, maka dapat disimpulkan bahwa: a) dengan menggunakan model pembelajaran project-based learning dapat meningkatkan kemampuan menulis anak usia dini melalui media komik kelas II SD Negeri 071057 Hiliweto Gido tahun pembelajaran 2020/2021, b) dengan menggunakan model pembelajaran project-based learning dapat memberi motivasi kepada siswa kelas II SD Negeri 071057 Hiliweto Gido dalam menulis menulis anak usia dini melalui media komik. Saran yang disampaikan oleh peneliti adalah: 1) bagi siswa, hasil penelitian ini mampu meningkatkan hasil belajar dan memotivasi siswa dengan berpedoman pada langkah-langkah model pembelajaran project-based learning, 2) bagi guru bahasa Indonesia SD Negeri 071057 Hiliweto Gido, hendak model pembelajaran project-based learning terus diterapkan terhadap pembelajaran menulis di sekolah.
\end{abstract}

Kata Kunci: Menulis Anak Usia Dini Melalui Penggunaan Media Komik, Model ProjectBased Learning, Siswa.

\begin{abstract}
\footnotetext{
${ }^{1}$ Guru SD Negeri 071057 Hiliweto Gido

Email : arozatulobawamenewi825@gmail.com
}

The purpose of this research is to improve the ability of early childhood writing students through comic media by applying a project-based learning model in improving early childhood writing skills through the comic media of grade II students of SD Negeri 071057 Hiliweto Gido in the 2020/2021 learning year. To achieve this goal, researchers use class action research methods with implementation procedures, namely: 1) planning, 2) actions, 3) observations, and 4) reflections. 
The subjects of this study were grade II students of SD Negeri 071057 Hiliweto Gido who numbered 30 people with a total of 16 men and 14 women. As a result of this study, it turns out that there is an increase in the ability of students to write early childhood through comic media with a project-based learning model. This can be seen from cycle I, with an average score of 64.5, a low of 45 and a top score of 80. Next, the result in cycle II, with an average value of 77.66, the lowest value is 70 and the highest value is 95 . The observation of students in cycle I was $78.33 \%$ and in cycle II was $93.33 \%$. The researchers' observations in the second meeting cycle I amounted to $72.22 \%$. While the observation of cycle II is the second meeting of $95.83 \%$. Based on the explanation above, it can be concluded that: a) by using project-based learning model can improve early childhood writing skills through the media of grade II comics sd Negeri 071057 Hiliweto Gido learning year 2020/2021, b) by using the learning model project-based learning can motivate students of grade II SD Negeri 071057 Hiliweto Gido in writing early childhood writing through comic media. The suggestions submitted by the researchers are: 1) for students, the results of this study are able to improve learning outcomes and motivate students by guided by the steps of the project-based learning model, 2) for Indonesian teachers of SD Negeri 071057 Hiliweto Gido, to continue to apply project-based learning model to writing learning in schools.

Keywords: Writing Early Childhood Through the Use of Comic Media, Project-based learning Model, Students.

\section{PENDAHULUAN}

Secara umum ada empat aspek keterampilan berbahasa yakni aspek keterampilan menyimak, berbicara, membaca, dan menulis. Empat aspek keterampilan itu tidak dapat terpisahkan satu sama lain. Keterampilan menyimak dan keterampilan membaca, yang samasama penggunaan bahasa pasif-reseptif, sedangkan keterampilan berbicara dan keterampilan menulis, keduanya sama-sama penggunaan bahasa aktif-produktif yang mengasumsikan adanya isi masalah yang hendak disampaikan kepada pendengar atau pembaca.

Djuharie (2001:121) mengatakan kegiatan menulis bagi setiap orang merupakan kegiatan yang mempunyai posisi sangat penting, selain untuk mengungkapkan gagasan dan pendapatnya juga dapat mengungkapkan isi hati dan curahan jiwa seseorang. Tarigan (2005:21) mengemukakan menulis adalah menurunkan atau melukiskan lambang-lambang grafik yang menggambarkan suatu bahasa yang dipahami oleh sesorang, sehingga orang lain dapat membaca grafik tersebut kalau mereka memahami bahasa dan gambar grafik itu.

Komik merupakan salah satu contoh cerita bergambar. Gambar dalam komik merupakan bentuk visualisasi dari cerita. Menurut Tedjasaputra (2007:66) yang dimaksud dengan komik adalah cerita bergambar dimana unsur gambar lebih penting dari pada ceritanya. Unsur gambar pada komik sangat penting untuk memahami jalan cerita. Jalan cerita pada komik dapat dipahami meskipun tanpa adanya penjelasan berupa kata-kata. Unsur gambar pada komik mempunyai peranan penting dalam alur cerita. Hal ini juga diungkapkan oleh Tigpen (2012:15), comic strips are a group of cartoons arranged into a narrative. Komik adalah kelompok kartun yang disusun menjadi narasi. Komik merupakan kumpulan gambar yang disusun menjadi sebuah serangkaian cerita.

Berdasarkan hasil wawancara peneliti kepada guru mata pelajaran bahasa Indonesia di SD Negeri 071057 Hiliweto Gido khususnya di kelas II menggambarkan bahwa kemampuan menulis anak usia dini melalui media komik masih belum memuaskan, lebih-lebih pada kompetensi menulis anak usia dini melalui media komik. Hal ini dibuktikan oleh hasil ulangan harian siswa, kemampuan menulis anak usia dini melalui media komik masih rendah, lebih dari $80 \%$ kemampuan siswa masih di bawah KKM 75 yang ditetapkan sekolah.

Berdasarkan permasalahan di atas mendorong minat peneliti, tergerak hati mencari solusi dalam memecahkan masalahan tersebut. Salah satu solusi yang peneliti lakukan yakni dengan 
menerapkan model pembelajaran. Model pembelajaran yang dimaksud adalah model pembelajaran project-based learning merupakan segala sesuatu yang diwujudkan secara visual ke dalam bentuk dua dimensi sebagai curahan ataupun pikiran untuk mendorong para siswa serta membangkitkan minatnya pada pembelajaran. Menurut Chatoer dalam Istarani (2012:156) mengatakan belajar berbasis proyek (project-based learning) adalah sebuah model atau pendekatan pembelajaran yang inovatif, yang menekankan belajar kontekstual melalui kegiatankegiatan yang kompleks.

\section{Tinjauan Teori}

\section{Menulis}

Menulis merupakan aktivitas membuat tulisan dari berbagai macam sumber baik sumber internal maupun sumber eksternal dengan menggunakan angka dan huruf tertentu yang dapat dimengerti penulisnya dan juga oleh orang lain. Menulis dapat diartikan sebagai aktivitas seseorang dalam menuangkan ide, gagasan yang disampaikan secara tertulis dengan menggunakan bahasa tulis sebagai alat atau medianya. Suparno (2008:1.3) mengatakan: Menulis merupakan suatu kegiatan penyampaian pesan (komunikasi) dengan menggunakan bahasa tulis sebagai alat atau medianya. Menulis dapat didefinisikan sebagai suatu kegiatan penyampaian pesan (komunikasi) dengan menggunakan bahasa tulis sebagai alat atau medianya. Selanjutnya, Tarigan (2005:21) mengatakan: Menulis ialah menurunkan atau melukiskan lambang-lambang grafik yang menggambarkan suatu bahasa yang dapat dipahami oleh orang lain, sehingga dapat pembaca dapat memahami lambang-lambang grafik tersebut.

1) Menulis berarti mengubah bunyi yang dapat didengar menjadi tanda- tanda yang dapat dilihat. bunyi-bunyi yang dapat diubah itu bunyi bahasa yaitu bunyi yang dihasilkan oleh alat ucap manusia.

2) Menulis mempunyai arti kegiatan mengungkapkan gagasan secara tertulis. Orang yang melakukan kegiatan ini dinamakan penulis dan hasil kegiatannya berupa tulisan."

\section{Media Komik}

Komik dianggap sebagai media pembelajaran yang dapat menjadi alat untuk meningkatkan motivasi menulis kata. Alur cerita yang dituangkan dalam panel-panel gambar akan membantu anak melihat jalan cerita. Ilustrasi-ilustrasi yang sesuai dalam sebuah komik membantu anak-anak dapat memahami sebuah cerita. Pemahaman cerita pada gambar dapat membantu anak untuk menuliskan dialog pada balon kata. Komik dapat menjadi media yang menarik, mudah dan menghibur, dalam penyampaian pembelajaran.

Komik merupakan salah satu contoh cerita bergambar. Gambar dalam komik merupakan bentuk visualisasi dari cerita. Menurut Tedjasaputra (dalam Juliati 2014:127) yang dimaksud dengan komik adalah cerita bergambar dimana unsur gambar lebih penting dari pada ceritanya. Unsur gambar pada komik sangat penting untuk memahami jalan cerita. Jalan cerita pada komik dapat dipahami meskipun tanpa adanya penjelasan berupa kata-kata. Unsur gambar pada komik mempunyai peranan penting dalam alur cerita. Hal ini juga diungkapkan oleh Tigpen (2012:15), comic strips are a group of cartoons arranged into a narrative. Komik adalah kelompok kartun yang disusun menjadi narasi. Komik merupakan kumpulan gambar yang disusun menjadi sebuah serangkaian cerita.

\section{Project-Based Learning}

Menurut Istarani (2012:156) mengatakan belajar berbasis proyek (project-based learning) adalah sebuah model atau pendekatan pembelajaran yang inovatif, yang menekankan belajar kontekstual melalui kegiatan-kegiatan yang kompleks. Fokus pembelajaran terletak pada konsep-konsep dan prinsip-prinsip inti dari suatu disiplin studi, melibatkan pembelajar dalam investigasi pemecahan masalah dan kegiatan tugas-tugas 
bermakna yang lain, memberi kesempatan pembelajar bekerja secara otonom mengonstruksi pengetahuan mereka sendiri, dan mencapai puncaknya menghasilkan produk nyata.

Selanjutnya, Aina Mulyana (2012) menjelaskan model pembelajaran berbasis proyek (project based learning) adalah metode pembelajaran yang menggunakan proyek/kegiatan sebagai media. Peserta didik melakukan eksplorasi, penilaian, interpretasi, sintesis, dan informasi untuk menghasilkan berbagai bentuk hasil belajar. Model atau metode belajar yang menggunakan masalah sebagai langkah awal dalam mengumpulkan dan mengintegrasikan pengetahuan baru berdasarkan pengalamannya dalam beraktivitas secara nyata.

Pembelajaran berbasis proyek dirancang untuk digunakan pada permasalahan komplek yang diperlukan peserta didik dalam melakukan insvestigasi dan memahaminya. Melalui model pembelajaran berbasis proyek (project-based learning), proses inquiry dimulai dengan memunculkan pertanyaan penuntun (a guiding question) dan membimbing peserta didik dalam sebuah proyek kolaboratif yang mengintegrasikan berbagai subjek (materi) dalam kurikulum. Pada saat pertanyaan terjawab, secara langsung peserta didik dapat melihat berbagai elemen utama sekaligus berbagai prinsip dalam sebuah disiplin yang sedang dikajinya. Model pembelajaran berbasis proyek (project based learning) merupakan investigasi mendalam tentang sebuah topik dunia nyata, hal ini akan berharga bagi atensi dan usaha peserta didik.

Langkah-langkah model pembelajaran berbasis proyek (project-based learning) sebagai berikut:

a) Penentuan Pertanyaan Mendasar (Start With the Essential Question).

Pembelajaran dimulai dengan pertanyaan esensial, yaitu pertanyaan yang dapat memberi penugasan peserta didik dalam melakukan suatu aktivitas. Mengambil topik yang sesuai dengan realitas dunia nyata dan dimulai dengan sebuah investigasi mendalam. Pengajar berusaha agar topik yang diangkat relevan untuk para peserta didik.

b) Mendesain Perencanaan Proyek (Design a Plan for the Project).

Perencanaan dilakukan secara kolaboratif antara pengajar dan peserta didik. Dengan demikian peserta didik diharapkan akan merasa "memiliki" atas proyek tersebut. Perencanaan berisi tentang aturan main, pemilihan aktivitas yang dapat mendukung dalam menjawab pertanyaan esensial, dengan cara mengintegrasikan berbagai subjek yang mungkin, serta mengetahui alat dan bahan yang dapat diakses untuk membantu penyelesaian proyek.

c) Menyusun Jadwal (Create a Schedule).

Pengajar dan peserta didik secara kolaboratif menyusun jadwal aktivitas dalam menyelesaikan proyek. Aktivitas pada tahap ini antara lain: (1) membuat timeline untuk menyelesaikan proyek, (2) membuat deadline penyelesaian proyek, (3) membawa peserta didik agar merencanakan cara yang baru, (4) membimbing peserta didik ketika mereka membuat cara yang tidak berhubungan dengan proyek, dan (5) meminta peserta didik untuk membuat penjelasan (alasan) tentang pemilihan suatu cara.

d) Memonitor Peserta Didik Dan Kemajuan Proyek (Monitor the Students and the Progress of the Project).

Pengajar bertanggungjawab untuk melakukan monitor terhadap aktivitas peserta didik selama menyelesaikan proyek. Monitoring dilakukan dengan cara menfasilitasi peserta didik pada setiap roses. Dengan kata lain pengajar berperan menjadi mentor bagi aktivitas peserta didik. Agar mempermudah proses monitoring, dibuat sebuah rubrik yang dapat merekam keseluruhan aktivitas yang penting.

e) Menguji Hasil (Assess the Outcome).

Penilaian dilakukan untuk membantu pengajar dalam mengukur ketercapaian standar, berperan dalam mengevaluasi kemajuan masing- masing peserta didik, memberi umpan balik tentang tingkat pemahaman yang sudah dicapai peserta didik, membantu pengajar dalam menyusun strategi pembelajaran berikutnya.

f) Mengevaluasi Pengalaman (Evaluate the Experience). 
Pada akhir proses pembelajaran, pengajar dan peserta didik melakukan refleksi terhadap aktivitas dan hasil proyek yang sudah dijalankan. Proses refleksi dilakukan baik secara individu maupun kelompok. Pada tahap ini peserta didik diminta untuk mengungkapkan perasaan dan pengalamanya selama menyelesaikan proyek. Pengajar dan peserta didik mengembangkan diskusi dalam rangka memperbaiki kinerja selama proses pembelajaran, sehingga pada akhirnya ditemukan suatu temuan baru (new inquiry) untuk menjawab permasalahan yang diajukan pada tahap pertama pembelajaran.

\section{METODE}

Berdasarkan tujuan yang akan dicapai, maka penelitian ini dilakukan dengan pelaksanaan penelitian tindakan kelas (PTK). Sanjaya (2009:16) mengatakan PTK adalah melaksanakan tanggung jawab guru sebagai researchers. Melalui PTK guru mengkaji masalah yang dihadapinya secara ilmiah yang didasarkan pada bukti-bukti empirik. Wardhani dan Wihardit (2012:115) mengatakan penelitian tindakan kelas (PTK) adalah penelitian yang dilakukan oleh guru di kelasnya sendiri melalui refleksi diri dengan tujuan untuk memperbaiki kinerjanya sehingga hasil belajar siswa meningkat. Sesuai dengan jenis penelitian ini yaitu PTK, maka penelitian ini memiliki beberapa tahapan pelaksanaan yaitu perencanaan, tindakan, observasi dan refleksi.

Pelaksanaan tindakan dalam penelitian ini direncanakan sebanyak dua siklus, setiap siklus terdiri dari dua kali pertemuan. Teknik analasis data dalam penelitian ini ada dua, yakni analisis data kuantitatif dan analisis data kualitatif.

\section{Analisis Data Kuantitatif}

a. Penskoran. Skor diberikan sesuai dengan kisi-kisi instrumen yang telah ditentukan sebelumnya.

b. Penjumlahan skor. Setelah lembaran hasil menyusun teks anekdot yang ditulis siswa diberi skor sesuai dengan kisi-kisi instrumen, maka setiap skor dijumlahkan untuk mendapat skor akhir.

c. Penentuan penilaian. Penentuan batas minimal kelulusan dan penilaian tertentu dapat dilakukan dengan perhitungan persentase penentuan nilai atau perhitungan persentase untuk skala 1-10.

\section{Analisis Data Kualitatif}

a. Reduksi data, yaitu menyeleksi dan mengelompokkan data berdasarkan informasi dan diorganisasikan sesuai dengan pertanyaan peneliti.

b. Paparan data, yaitu bahwa data yang sudah terorganisasi dikelompokkan atau dideskripsikan sampai bermakna dalam bentuk tabel atau grafik ataupun dinarasikan.

c. Penyimpulan, yaitu bahwa berdasarkan paparan yang telah dibuat ditarik suatu kesimpulan dalam bentuk pernyataan atau formulasi.

\section{HASIL DAN PEMBAHASAN}

Penelitian tindakan kelas ini dilaksanakan di SD Negeri 071057 Hiliweto Gido Kecamatan Gido Kabupaten Nias. Subjek penelitian adalah kelas II yang berjumlah 20 orang. Sebelum penelitian dilakukan, terlebih dahulu peneliti konsultasi kepada kepala sekolah SD Negeri 071057 Hiliweto Gido dan kepada guru mata pelajaran bahasa Indonesia yang mengajar di kelas II. Pelaksanaan penelitian ini mengikuti alur atau tahapan yaitu perencanaan, tindakan, observasi, dan refleksi.

Penelitian ini dilaksanakan sebanyak dua kali pertemuan dan satu kali pertemuan pemberian tes hasil belajar setiap siklus. Pelaksanaan penelitian ini disesuaikan dengan jadwal pada mata pelajaran di kelas II. Pelaksanaan penelitian dilakukan secara kolaborasi yaitu dengan menggunakan jasa pengamat lain yakni guru mata pelajaran pendidikan bahasa Indonesia di kelas II yang membantu dalam pelaksanaan observasi selama penelitian berlangsung, sehingga kegiatan penelitian ini dapat terlaksana dengan baik. Kegiatan peneltian dilaksanakan bertepatan 
pada jam pembelajaran bahasa Indonesia sehingga tidak mengganggu proses pelaksanaan pembelajaran yang lain dan juga peneliti sekaligus sebagai praktisi tidak perlu meninggalkan kelas selama proses pembelajaran berlangsung.

Penelitian tindakan kelas ini dilakukan dengan empat tahapan yaitu: perencanaan, tindakan, observasi, dan refleksi yang disajikan dalam dua siklus sebagai berikut:

\section{Siklus I}

\section{Pembelajaran Pada Siklus I}

Pada pembelajaran siklus I dengan materi menulis anak usia dini melalui media komik dilakukan beberapa tahap mulai dari tahap perencanaan yaitu menyusun rencana pelaksanaan pembalajaran dengan menerapkan Project-based learning, menetapkan waktu pelaksanaannya, menyiapkan lembar observasi, menyiapkan naskah tes hasil belajar siswa. Setelah tahap perencanaan maka tahap berikutnya berupa tindakan dimana seluruh proses kegiatan belajar mengajar dengan menerapkan project-based learning dilaksanakan. Tahap berikutnya adalah observasi, dimana selama proses pembelajaran berlangsung guru mata pelajaran bahasa Indonesia bertindak sebagai pengamat dan mengisi lembaran observasi yang telah disediakan peneliti, dan setelah itu dilakukan refleksi yang tujuannya untuk mengetahui kelemahan-kelemahan disaat proses pembelajaran berlangsung.

\section{Hasil Observasi Untuk Guru Pada Siklus I}

Hasil observasi guru pada siklus I adalah pada pertemuan pertama $55,88 \%$ predikat "Kurang" sedangkan pertemuan kedua $72,22 \%$. predikat "Cukup". Maka hasil observasi guru atau peneliti dalam proses pembelajaran masih digolongkan cukup. Pada pembelajaran ini ada beberapa indikator yang masih belum dicapai klasifikasi baik, oleh karena itu perlu dilakukan perbaikan pada siklus berikutnya.

\section{Hasil Observasi Siswa Pada Siklus I}

Hasil observasi siswa pada siklus I pertemuan pertama sebesar 59,33\% predikat "Kurang" dan pertemuan kedua sebesar 78,33\% predikat "cukup". Pada pertemuan ini aktivitas siswa masih belum mencapai target yang diharapkan sehingga perlu ditingkatkan pada siklus II.

\section{Hasil Belajar Pada Siklus I}

Hasil belajar siswa diperoleh dengan menggunakan tes menulis anak usia dini melalui media komik dengan menggunakan langkah-langkah model pembelajaran project-based learning. Berdasarkan perolehan siswa pada tes hasil belajar siklus I, maka rata-rata 64,5\%.

\section{Refleksi Siklus I}

Refleksi dilakukan berdasarkan hasil pelaksanaan penelitian tindakan kelas pada siklus I, yaitu mengungkapkan kembali temuan dan kelemahan selama pelaksanaan penelitian. Sebagai refleksi pada siklus I adalah:

a) Pelaksanaan proses pembelajaran dengan menerapkan model pembelajaran project-based learning pada materi menulis anak usia dini melalui media komik ditingkatkan karena berdasarkan hasil pengamatan pelaksanaan pembelajaran masih belum memuaskan yakni hanya mencapai nilai rata-rata $72,22 \%$ predikat "Cukup". Peneliti lebih memperhatikan cara belajar siswa dan melakukan model yang baik kepada siswa, sehingga pada siklus II dapat mencapai tujuan pembelajaran.

b) Aktivitas belajar siswa selama mengikuti proses pembelajaran melalui model pembelajaran project-based learning pada materi menulis anak usia dini melalui media komik mencapai nilai rata-rata 78,33\% predikat "cukup". Untuk mencapai hasil belajar siswa, peneliti memperhatikan aktivitas siswa dalam proses pembelajaran dan melakukan pendekatan kepada siswa sehingga tidak ada siswa yang malas, ngantuk, ribut, keluar masuk ruangan, dan pada siklus II dapat meningkatkan hasil aktivitas belajar siswa. 
c) Perolehan nilai pengetahuan (Penilaian KI-3) perlu ditingkatkan karena nilai rata-rata yang diperoleh $=64,5 \%$ dengan predikat "Kurang".

\section{Siklus II}

\section{Pembelajaran Pada Siklus II}

Pembelajaran siklus II dilaksanakan dua kali pertemuan dengan menerapkan model pembelajaran project-based learning. Pelaksanaan penelitian ini dilakukan berdasarkan pada waktu yang telah ditetapkan sebelumnya. Selama proses pembelajaran berlangsung, guru mata pelajaran bahasa Indonesia hadir di ruang kelas dan bertindak sebagai pengamat yaitu dengan melakukan pengamatan terhadap proses pembelajaran yang dilakukan oleh peneliti dan juga aktivitas yang dilakukan siswa selama pembelajaran berlangsung sesuai dengan indikator yang telah disediakan sebelumnya pada lembar observasi.

\section{Hasil Observasi Untuk Guru Pada Siklus II}

Hasil observasi guru pada siklus II mengalami peningkatan bila dibandingkan pada siklus I dimana presentase pengamatan yang dilakukan oleh guru bahasa Indonesia pada pertemuan pertama sebesar $85,78 \%$ predikat "Baik" sedangkan pada pertemuan kedua sebesar 95,83\%. predikat "Baik Sekali"

\section{Hasil Observasi Siswa Pada Siklus II}

Hasil observasi siswa pada siklus II pertemuan pertama sebesar 88,33\% predikat "baik", sedangkan pada pertemuan kedua sebesar 93,33\% predikat "Baik Sekali". Berdasarkan hasil yang didapatkan pada siklus II ini, maka aktivitas siswa telah mencapai target yang telah diharapkan tanpa melanjutkan pada siklus berikutnya.

\section{Hasil Belajar Pada Siklus II}

Hasil belajar siswa diperoleh dengan menggunakan tes menulis anak usia dini melalui media komik dengan menggunakan langkah-langkah model pembelajaran project-based learning. Berdasarkan perolehan siswa pada tes hasil belajar siklus II, jumlah siswa yang dinyatakan tuntas adalah 30 orang dengan presentase $100 \%$.

\section{Refleksi Siklus II.}

Berdasarkan hasil yang didapatkan baik pada lembar observasi siswa maupun guru telah memenuhi tingkat klasifikasi penilaian sehingga refleksi pada pembelajaran siklus II tidak perlu diadakan karna sesuai dengan yang diharapkan.

\section{SIMPULAN}

Berdasarkan hasil penelitian ini, maka penulis menyimpulkan sesuai dengan temuan penelitian yang telah dilakukan adalah sebagai berikut:

1. Pada siklus I peningkatan kemampuan siswa dengan nilai terendah yaitu 45 dengan predikat " kurang" dan nilai tertinggi 80 dengan predikat "sangat baik" dengan nilai rata-rata 64,5\% dengan predikat "kurang". Pada siklus II Peningkatan Kemampuan Siswa dengan nilai terendah yaitu 70 dengan predikat "baik" dan nilai tertinggi 95 dengan predikat "sangat baik" dengan nilai rata-rata $77,66 \%$ dengan predikat "sangat baik".

2. Lembar observasi peneliti pada siklus I pertemuan I sebesar $85,78 \%$ predikat "Baik" sedangkan pada pertemuan kedua sebesar 95,83\%. predikat "Baik Sekali". Sedangkan Siklus II lembar observasi peneliti pada pertemuan pertama sebesar $85,78 \%$ predikat "Baik" sedangkan pada pertemuan kedua sebesar 95,83\%. predikat "Baik Sekali"

3. Lembar observasi siswa pada siklus I pertemuan I sebesar 59,33\% predikat "Kurang" dan pertemuan kedua sebesar 78,33\% predikat "cukup". Sedangkan Siklus II lembar observasi siswa pada pertemuan pertama sebesar $88,33 \%$ predikat "baik", sedangkan pada pertemuan kedua sebesar 93,33\% predikat "Baik Sekali". 
4. Dengan hasil penjelasan diatas maka ada peningkatan kemampuan menulis anak usia dini melalui media komik dengan menggunakan model pembelajaran project-based learning.

5. Dengan menggunakan model pembelajaran project-based learning dapat memberi motivasi dan keaktifan siswa dalam materi pembelajaran menulis anak usia dini melalui media komik di kelas II SD.

\section{DAFTAR PUSTAKA}

Aina Mulyana (2012). Pengertian Model Pembelajaran Kontekstual (http://ainamulyana.blogspot.com/2012/01/pengertianmetodepembelajaran-dan.html) diakses pada 12/02/2021.

Akhadiah (1989) Pembinaan Keterampilan Menulis Bahasa Indonesia, Erlangga, Jakarta.

Arikunto, Suharsimi., Suhardjono, Supardi (2006) Penelitian Tindakan Kelas, PT. Bumi Aksara, Jakarta.

Djuharie, Otong Setiawan (2001). Pedoman Penulisan Skripsi, Tesis, Disertasi. Yrama Widya, Bandung.

Istarani (2012). 58 Model Pembelajaran Inovatif. Medan: Media Persada.

Juliati, Andini Diana (2014). Peningkatan Motivasi Menulis Anak Usia 5-6 Tahun Melalui Penggunaan Media Komik. Vol. 9 No. 2 Desember 2014

Tarigan, Henry Guntur (2005) Menulis Sebagai Suatu Keterampilan Berbahasa. Angkasa, Bandung.

Tedjasaputra, M.S (2007). Bermain Mainan dan Permainan. Jakarta: PT. Grasindo

Tigpen, N.T (2012). "Thesis Decoding Comic: Essential Elements for Transcriptio". Journal: Lousiana State University and Agricultural and Mechanical College.

Sanjaya, Wina (2009). Penelitian Tindakan Kelas. Jakarta : Kencana.

Suparno (2008). Ketrampilan Dasar Menulis. Jakarta : Universitas Terbuka

Uno, Hamzah (2008), Model Pembelajaran Menciptakan Proses Belajar Mengajar yang Kreatif dan Efektif. Bumi Aksara, Jakarta.

Yunus, Suprno (2011) Keterampilan Menulis. Universitas Terbuka, Jakarta.

Wardhani, IGAK dan Wihardit, Kuswaya (2008). Penelitian Tindakan Kelas. Jakarta : Universitas Terbuka 